\title{
Advantage in muscle activation in gait with support of body weight in spinal cord injury
}

\author{
Vantagem na ativação muscular na marcha com \\ suporte de peso corporal em lesados medulares
}

\section{Ventaja en la activación muscular en la marcha con el apoyo del peso corporal en la lesión de la médula espinal}

\author{
Jéssica Saccol Borin ${ }^{[a]}$, Tânia Valdameri Capelari ${ }^{[a]}$, Melissa Grigol Goldhardt ${ }^{[b]}$, \\ Márcia Cristina Issa ${ }^{[\mathrm{b}]}$, Diego Antônio Pereira Bica dos Santos ${ }^{[\mathrm{b}]}$, Fernanda Cechetti ${ }^{[\mathrm{a}]^{*}}$
}

[a] Universidade Federal de Ciências da Saúde de Porto Alegre (UFCSPA), Porto Alegre, RS, Brazil

[b] Clínica de Reabilitação Neurofuncional Melissa Grigol, Porto Alegre, RS, Brazil

\begin{abstract}
Introduction: The locomotor training with body weight support has been proposed as an alternative for the rehabilitation of people with spinal cord injury, in order to develop most of the residual potential of the body. Objective: To compare the levels of muscle activation of the main muscle involved in gait during body weight-supported treadmill training and body weight-supported overground training in incomplete spinal cord injured patients. Methods: It was a prospective cross-sectional study, in which 11 incomplete injured patients were submitted to two modalities of gait with body weight support, the first one on the
\end{abstract}

"JSB: MS, e-mail: jessicasaccolborin@gmail.com TVC: MS, e-mail: tvcapelari@gmail.com MGG: MS, e-mail: megrigol@yahoo.com.br MCI: undergrad, e-mail: marcinhaissa@gmail.com DAPBS: undergrad, e-mail: diego-pb@hotmail.com FC: PhD, e-mail: fernandacec@ufcspa.edu.br 
treadmill (two different speeds: 1 and $4 \mathrm{~km} / \mathrm{h}$ ), and the second one with the walker on fixed floor. The electromyographical acquisition was done in the rectus femoris (RF), vastus medialis (VM), vastus lateralis (VL) and gluteus maximus (GM). Results: There was a greater muscle activation of all muscles analyzed in the treadmill training as compared to the over groundtraining, both at $4 \mathrm{~km} / \mathrm{h}$ (RF: $\mathrm{p}=0.00)$, (VM: $\mathrm{p}=0.00$ ), (VL: $\mathrm{p}=0.00$ ) e (GM: $\mathrm{p}=0.00$ ) and at $1 \mathrm{~km} / \mathrm{h}(\mathrm{RF}: \mathrm{p}=0.00$ ), (VM: $\mathrm{p}=0.00)$, (VL: $\mathrm{p}=0.00$ ) e (GM: $\mathrm{p}=0.00$ ). When comparing the two modalities of treadmill training, at 4 and $1 \mathrm{~km} / \mathrm{h}$, there was no statically significant difference between them (RF: $p=0.36$ ), (VM: $p=1.00)$, (VL: $p=1.00)$ e (GM: $p=0.16)$. Conclusion: The gait training with body weight support is more effective in activating the muscles involved in the gait training on treadmill compared to overground training in patients with incomplete spinal cord injury.

Keywords: Spinal Cord Injuries. Gait. Electromyography. Neurological Rehabilitation.

\section{Resumo}

Introdução: $O$ treino de marcha com suporte de peso corporal tem sido proposto como uma alternativa para a reabilitação de pessoas com lesão medular (LM), com o intuito de desenvolver ao máximo o potencial residual do organismo. Objetivo: Comparar os níveis de ativação muscular dos principais músculos envolvidos na marcha durante a deambulação, com suporte de peso corporal na esteira e no andador em piso fixo em pacientes lesados medulares incompletos. Métodos: Tratou-se de um estudo transversal, no qual 11 pacientes lesados medulares incompletos foram submetidos a duas modalidades de treino de marcha com suporte de peso corporal, a primeira na esteira (em duas diferentes velocidades: 1 e $4 \mathrm{~km} / \mathrm{h}$ ) e a segunda no andador em piso fixo. Foi realizada a aquisição do EMG nos músculos reto femoral (RF), vasto medial (VM), vasto lateral (VL) e glúteo máximo (GM). Resultados: Houve uma maior ativação muscular de todos os músculos analisados no treino na esteira quando comparado ao treino em andador, tanto a $4 \mathrm{~km} / \mathrm{h}(R F: p=0,00)$, (VM: $p=0,00)$, (VL: $p=0,00)$ e (GM: $p=0,00)$, como a $1 \mathrm{~km} / \mathrm{h}$ (RF: $p=0,00)$, (VM: $p=0,00)$, (VL: $p=0,00)$ e (GM: $p=0,00)$. Quando comparadas as duas modalidades de treino na esteira, a 4 e $1 \mathrm{~km} / \mathrm{h}$, não houve diferença estatisticamente significativa entre elas (RF: $p=0,36),(V M: p=1,00),(V L: p=1,00)$ e (GM: $p=0,16)$. Conclusão: A principal conclusão desta pesquisa foi que o treino de marcha com suporte de peso corporal ativou mais a musculatura dos músculos envolvidos na marcha no treino na esteira em relação ao treino no andador em piso fixo em pacientes com LM incompleta.

Palavras-chave: Traumatismos da Medula Espinhal. Marcha. Eletromiografia. Reabilitação Neurológica.

\section{Resumen}

Introducción: El entrenamiento locomotor con soporte de peso corporal se ha propuesto como una alternativa para la rehabilitación de personas con lesión medular, con el fin de desarrollar la mayor parte del potencial residual del cuerpo. Objetivo: Comparar los niveles de activación muscular del músculo principal involucrado en la marcha durante el entrenamiento de la cinta rodante respaldado por el peso corporal y el entrenamiento de sobrepeso soportado por el peso corporal en pacientes lesionados incompletos de la médula espinal. Métodos: Se trató de un estudio transversal prospectivo, en el que 11 pacientes incompletos lesionados fueron sometidos a dos modalidades de marcha con soporte de peso corporal, el primero en la cinta de correr (dos velocidades diferentes: 1 y $4 \mathrm{~km} / \mathrm{h}$ ) y el segundo Uno con el andador en el piso fijo. La adquisición electromiográfica se realizó en el recto femoral (RF), vasto medial (VM), vasto lateral (VL) y glúteo mayor (GM). Resultados: Hubo una mayor activación muscular de todos los músculos analizados en el entrenamiento de la rueda de ardilla en comparación con el entrenamiento sobre el suelo, tanto a $4 \mathrm{~km} / \mathrm{h}$ (RF: $p=0,00)$, (VL: $p=0,00)$ e (GM: $p=0,00)$ y a $1 \mathrm{~km} / \mathrm{h}(R F: p=0,00),(V M: p=0,00),(V L: p=0,00)$ e (GM: $p=0,00)$. Al comparar las dos modalidades de entrenamiento en cinta rodante, a 4 y $1 \mathrm{~km} / \mathrm{h}$, no hubo diferencia estadísticamente significativa entre ellas (RF: $p=0,36),(V M: p=1,00),(V L: p=1,00)$ e (GM: $p=0,16)$. Conclusión: El entrenamiento de la marcha con el apoyo 
del peso corporal es más eficaz en la activación de los músculos involucrados en el entrenamiento de la marcha en cinta ergométrica en comparación con el entrenamiento en el suelo en pacientes con lesión incompleta de la médula espinal.

Palabras clave: Lesiones de la médula espinal. Paso. Electromiografía. Rehabilitación Neurológica.

\section{Introduction}

Spinal cord injury (SCI) is a global health problem that afflicts young adults and the elderly. Motor vehicle accidents and falls remain the leading cause of SCI. It is becoming a significant social burden due to improved survival rate and access to care [1]. Every year, around the world, between 250,000 and 500,000 people suffer a spinal cord injury [2].

Rehabilitation after SCI aims to increase functional mobility and improve quality of life. At 1-year postinjury, $\sim 41 \%$ of persons with SCI are classified as having chronic motor-incomplete SCI [3]. Thus, the disability of walking or the slow paretic gait with high cost of energy proves to be the most visible persistent disability after spinal cord injury [4].

Restoration of walking ability is an area of great interest in the rehabilitation of persons with spinal cord injury. Because many cortical, subcortical, and spinal neural centers contribute to locomotor function, it is important that intervention strategies be designed to target neural elements at all levels of the neuraxis that are important for walking ability [5]. The recovery of gait in spinal cord injury becomes a difficult and expensive task, as the patients are often unable to produce muscle strength to maintain posture and walk, being necessary to provide support to protect these people from falls. The conventional systems to help gait such as parallel bars, crutches, and canes do not propitiate the relief of weight quantity because it is not constant or easily quantifiable [6].

Aiming to fully develop the residual potential of the body and assist the reintegration into family, social and professional life, body weight-supported gait training (BWSGT) has been proposed as an alternative for the rehabilitation of people with spinal cord injury, maximizing afferent input from peripheral joints can provide task-specific stimulation to the central nervous system to promote neuroplasticity and currently is performed on the treadmill and in the walker [7].

Body weight-supported training is a suspension system that reduces the resulting force between the gravitational strength and the suspension strength, decreasing the load over the musculoskeletal structure. The suspension partially supports the patient's weight, making gait easier [8]. The easier gait also occurs due to greater trunk control [9], the aid on treadmill exercise and the manual help of the physiotherapist who can work with the impaired gait features [10].

On the other hand, body weight-supported overground training can be a more specific way of training than on treadmill and can make the transition to walk easier during therapy in a real environment. On the treadmill, the floor moves in relation to the patient, but the visual stimulus remains the same, since people move in relation to the floor. Thus, the overground training is probably more adequate because it is a simulation of the real world $[11,12]$.

Physiotherapeutic procedures to spinal cord injured patients in order to regain the ambulation function include repetitive and intense practice of walking motion with or without treadmill. To improve the use of antigravity muscles, the removal of part of body weight associated with treadmill or walker may be an option, but there is still no evidence to conclude on which specific locomotor training is more effective to improve the deambulation ability of people with spinal cord injury. Therefore, well-defined training strategies are still needed to optimize the use of this intervention with body weight-support for the rehabilitation of gait.

This research aimed to compare the muscle activation levels during gait with body weight-support on treadmill and overground in patients with incomplete spinal cord injury. 


\section{Methods}

\section{Participants}

A cross-sectional study was developed with incomplete spinal cord injured patients. This study was approved by the Ethics and Research Committee of Federal University of Health Sciences (934.860) and was registered in the clinical trials (RBR-37tjbg).

A convenience sample was recruited at the Neurofunctional Rehabilitation Clinic Melissa Grigol, in Porto Alegre, Rio Grande do Sul, Brazil. The inclusion criteria were: patients with clinical diagnosis of incomplete spinal cord injury for more than 6 months and who accepted to sign the Free and Informed Consent (FIC). Subjects presenting contraindication to the use of weight support, such as hip fracture, lower limb fracture, or decubitus ulcers were excluded, as well as patients with unstable angina or another decompensated heart disease, chronic obstructive pulmonary disease, associated neurological diseases or symptomatic low blood pressure while in the upright position.

\section{Procedures}

The participants included in the study were classified by the American Spinal Injury Association (ASIA), based on the evaluation of sensitive and motor levels, being organized in categories or disability levels, named by the letters A, B, C, D and E, in descending degree of disorder or disability [13].

The functionality of the individuals in the research was evaluated by the Functional Independence Measure (FIM) scale, a multidimensional tool that evaluates the individual's performance in the motor cognitive/ social aspects. Each item was scored from 1 to 7 , the total scale. A person without any disability reaches the score of 126 points and the one with total dependence, the score of 18 points [14].

In order to classify the muscle tone of the individuals involved in spastic or flaccid, the classification according to Dobkim, Apple, et al. was used [15]: individuals who had injury at cervical level until T10 were classified as having upper motor neuron injury (UMN - spastic); individuals with injury from T11 to L3 were classified as having lower motor neuron injury (LMN - flaccid).
Besides, for spastic individuals, the muscular tonus of right lower limb quadriceps muscles was evaluated with modified Ashworth (graded from 0 to 4, being 0 a normal tonus and 4 , severe increase in muscle tonus that affected parts are rigid in flexion or extension) [16].

To collect the electromyographic signal, the electromyography (New MiotoolFisio, Miotec, Porto Alegre, RS), sampling rate of $2000 \mathrm{~Hz} / \mathrm{channel}$, eight channels and connected to laptop (HP/Window 7), software Miograph (Miotec, Porto Alegre, RS) was used. For the signal capture, disposable adhesive electrodes Meditrace 200 (Kendall, USA) were used, measuring $10 \mathrm{~mm}$ in diameter and bipolar configuration. Center to center distance between electrodes was $20 \mathrm{~mm}$, as recommended by SENIAM. To perform the collection procedure, the impedance of the skin was reduced by aseptic and light abrasion with cotton soaked in alcohol $70 \%$, based on the International Society of Electrophysiology and Kinesiology guidelines. To follow the muscle action potential, ensuring a better acquisition of EMG, signal electrodes were placed longitudinally to the muscle fibers [17].

The electrodes were positioned in order to allow the capture of EMG signal of muscles involved in gait and fixed on the muscle belly of the rectus femoris (RF), vastusmedialis (VM), vastuslateralis (VL), and gluteus maximus (GM) of the right leg. The reference electrode was positioned on the tibial tuberosity of the same leg.

To carry out the electromyography, patients were first conducted to the body weight-support treadmill. The treadmill (Extreme 3000, Athletic, Manaus, AM) was supported by the Hip Positioner (Pacer Gait Trainer, Rifton, Rifton, NY), which was fastened by nylon straps to a galvanic iron railing set to the roof with parabolts. The individuals were positioned on the weight support with the aid of two physiotherapists. The height of the safety belts were measured according to the adequate position of the patient on the treadmill. The weight support belt was adjusted to maximize the load bilaterally without deformation of the knee during upright posture. To assist in the gait, manual assistance by the physiotherapists in each leg of the patient was provided. A physiotherapist's hand was placed over the anterior surface of the leg below the patella to help in knee extension during gait. The other hand was placed on the ankle to help with the movement of the feet during the swing and the heel positioning in the starting position [18] (Figure 1). 


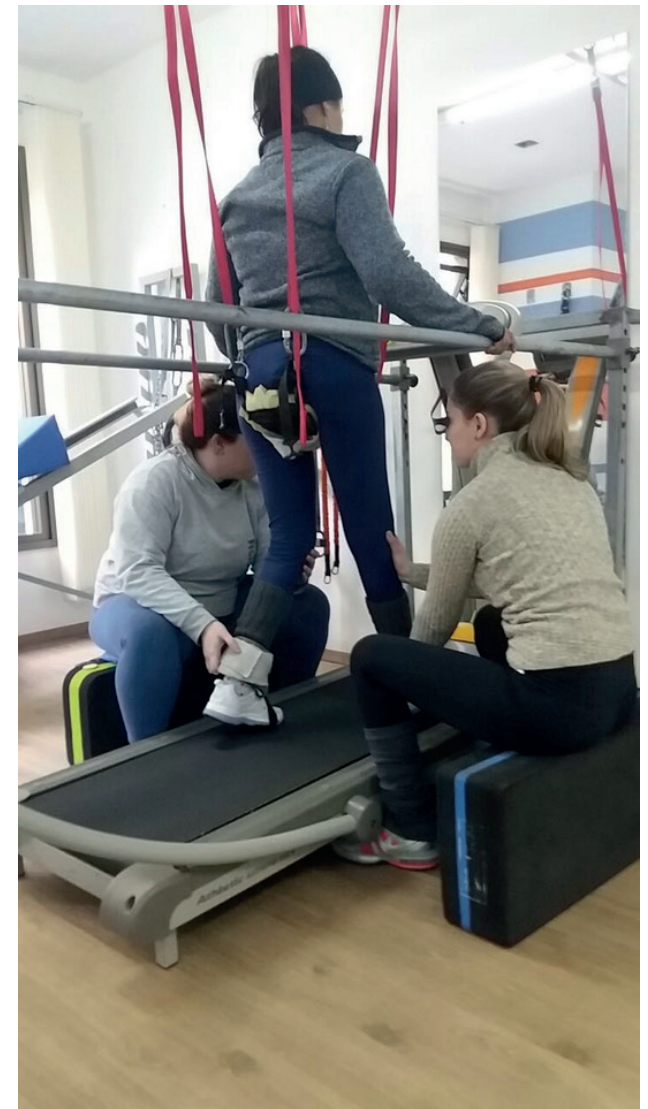

Figure 1 - Patient positioning and physical therapists for gait training on the treadmill with body weight support.

Data acquisition on the treadmill was held in two stages, the first one at the running speed of $1 \mathrm{~km} / \mathrm{h}$ and the second, at $4 \mathrm{~km} / \mathrm{h}$.

After training on the treadmill, the patients were transferred to the adaptative walker (Pacer Gait Trainer, Rifton, Rifton, NY) with the Hip Positioner (Pacer Gait Trainer, Rifton, Rifton, NY), with help of the two physiotherapists. Decisions on the weight to be suspended on the overground walker were made with the gait pattern analysis, where the heel should make contact with the floor, and during the support phase of the gait, the knee should not be flexed [19]. The conduct on the aid of the gait was performed with a physiotherapist guiding the walker and the other positioned behind the patient helping in the flexion and extension of the knees. The gait speed in the overground walker depended on the capacity of each patient (Figure 2).

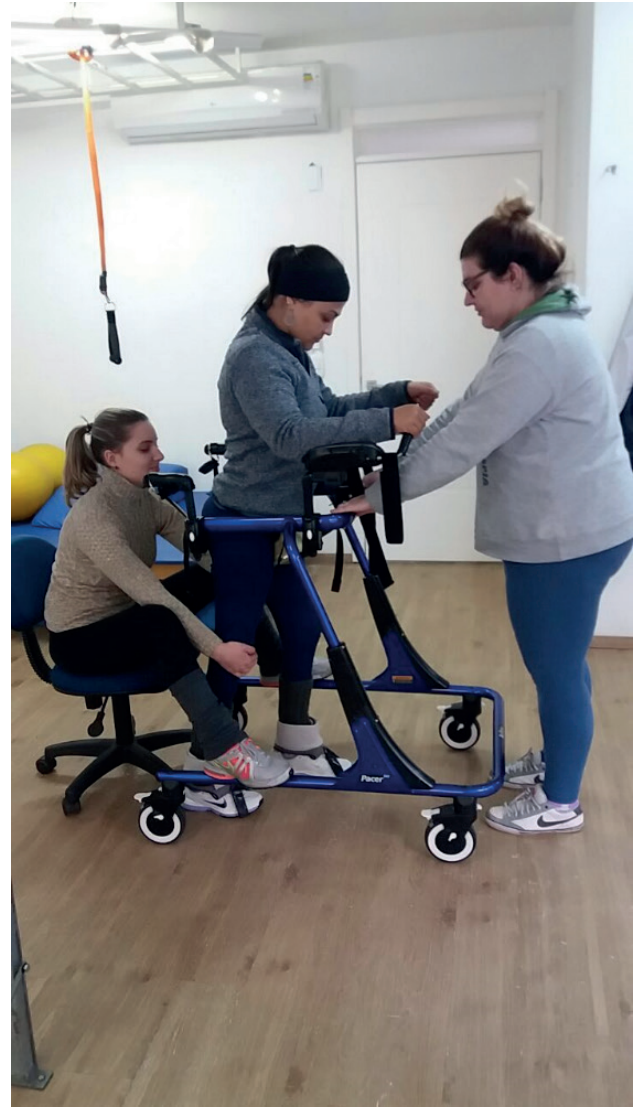

Figure 2 - Patient positioning and physical therapists for gait training in walker on a fixed platform with body weight support.

Procedures of electrodes positioning, data acquisition and transfer of the patients to the weight support were performed by a single researcher, and for the evaluation of gait training on the treadmill and in the walker the help of another skilled physiotherapist was needed.

Gait training on the treadmill at $1 \mathrm{~km} / \mathrm{h}, 4 \mathrm{~km} / \mathrm{h}$, and overground lasted 15 minutes each with an interval of 30 minutes between each mode, where the participants remain at rest so that fatigue was avoided. Also, in the two modalities patients made use of ankle-foot orthesis (Apoio Anti-Equino - Stus, Salvapé, São Paulo, SP).

\section{Statistical analysis}

In order to meet the research objectives, data interpretation and analysis were developed from 
the observed evidence, relating the theoretical reference with the positioning of the author. To determine the sample size with a statistical power of $80 \%$ and a significance level of $0.05,11$ patients per each training mode were needed. Calculation was done with GPower software, measured by muscle activation variable.

The quantitative results were presented as mean \pm standard deviation and the qualitative through frequency and percentage. Result measures were analyzed to verify if there are differences between the gait modalities using repeated measures ANOVA associated with post-hoc Bonferroni test. Comparison of muscle activation with spasticity was analyzed by with Student t-test and muscle activation with FIM through Pearson's correlation coefficient. The significance level was $5 \%$. Statistical analysis was performed using SPSS ${ }^{\circledR}$ 23.0 (Statistical Package for the Social Sciences, Inc., Chicago, IL, USA).

\section{Results}

Eleven subjects with incomplete spinal cord injury participated of the study. All participants were familiar with body weight-supported gait training on a treadmill and body weight-supported overground training.

The clinical characteristics of the patients with spinal cord injury are presented in Table 1 , indicating age, gender, FIM, ASIA, classification of affected motor neurons, Ashworth scale of muscle spasticity with spastic patients.

Table 1 - Demographics characteristics of participants

\begin{tabular}{|c|c|c|}
\hline & $(n=11)$ & \\
\hline Age - (years) mean (SD) & $38.36(10.98)$ & \\
\hline Gender (male) - n (\%) & $7(63.6)$ & \\
\hline FIM - mean (SD) & $108.9(15.2)$ & \\
\hline ASIA C - n (\%) & $11(100)$ & \\
\hline LMNI - n (\%) & $4(36.4)$ & \\
\hline UMNI - n (\%) & $7(63.6)$ & Ashworth Quadriceps - 1 \\
\hline
\end{tabular}

Note: $\mathrm{n}$ - sample; SD - Standart Deviation; FIM - Functional Independence Measure; ASIA - American Spinal Injury Association; LMNI lower motor neuron injury; UMNI - upper motor neuron injury. male, mean age of all participants was 38.36, showing that they have some kind of independence. According to the ASIA classification, all patients were considered ASIA C (motor preservation below the neurological level, with most of the key-muscles below this level with muscle strength degree under three). Patients were also evaluated according to the involved motor neuron, 4 of them presented injury in the lower motor neuron, and 7 , injury in higher motor neuron, showing spastic spinal cord injury grade 1 in the quadriceps, a level considered low, with increased tone at the beginning or at the end of the arc of movement, not resisting gait training.

Muscle activity patterns were analyzed for each of the 3 gait modes. The electrical activity of RF, VM, VL, and GM muscles were measured during body weightsupported gait training on the treadmill at $1 \mathrm{~km} / \mathrm{h}$, and $4 \mathrm{~km} / \mathrm{h}$ overground, in accordance with the capacity of each individual. Data acquisition was performed in 30 seconds in each mode and visualization was softened in non-standardized form. To obtain the results, the average of muscle activation of each muscle was used.

For all the analyzed muscles and in all subjects, the averages of electrical activity showed the same behavior. The greater muscle activation occurred on the treadmill, having no statistically significant difference between the speed of $1 \mathrm{~km} / \mathrm{h}$ or $4 \mathrm{~km} / \mathrm{h}$ (RF: $\mathrm{p}=0.36)$, (VM: $\mathrm{p}=1.00$ ), (VL: $\mathrm{p}=1.00$ ) and (GM: $\mathrm{p}=0.16$ ). Between the training on the treadmill, in any speed, and the walker, there was statistically significant difference between all the values of electric muscle activity [walker $x$ treadmill $1 \mathrm{~km} / \mathrm{h}$ (RF: $\mathrm{p}=0.00),(\mathrm{VM}: \mathrm{p}=0.00),(\mathrm{VL}: \mathrm{p}=0.00)$, and (GM: $\mathrm{p}=0,00)$ ] and [walker $x$ treadmill $4 \mathrm{~km} / \mathrm{h}$ (RF: $\mathrm{p}=0.00$ ), (VM: $\mathrm{p}=0.00$ ), (VL: $\mathrm{p}=0.00$ ) and (GM: $\mathrm{p}=0.00)$ ], proving greater muscle activation on the treadmill training (Tables 2 and 3 ).

$$
(\mathrm{n}=11)
$$

$36(10.98)$
As we can see in Table 1, most of the participants were 
Table 2 - Muscle activation values, according to electromyography signal (EMG)

\begin{tabular}{ccccc}
\hline & Mean $1 \mathrm{~km} / \mathrm{h}$ & Mean $4 \mathrm{~km} / \mathrm{h}$ & Mean Overground & p-value* \\
\hline RF $\mu$ V (SD) & $15.95^{\mathrm{a}}(6.22)$ & $21.26^{\mathrm{a}}(16.82)$ & $11.23^{\mathrm{b}}(1.13)$ & $<0.001$ \\
$\mathrm{VM} \mu$ V (SD) & $18.10^{\mathrm{a}}(9.21)$ & $20.80^{\mathrm{a}}(12.77)$ & $11.60^{\mathrm{b}}(2.76)$ & $<0.001$ \\
$\mathrm{VL} \mu \mathrm{V}$ (SD) & $16.82^{\mathrm{a}}(5.39)$ & $18.10^{\mathrm{a}}(8.14)$ & $12.26^{\mathrm{b}}(1.48)$ & $<0.000$ \\
$\mathrm{GM} \mu$ V (SD) & $18.64^{\mathrm{a}}(15.25)$ & $20.45^{\mathrm{a}}(16.73)$ & $11.14^{\mathrm{b}}(1.15)$ & $<0.015$ \\
\hline
\end{tabular}

Note: RF - Rectus Femoris; VM - Vastus Medialis; VL - Vastus Lateralis; GM - Gluteus Maximus; $\mu \mathrm{V}$ - microvolts; SD - Standart Deviation. *ANOVA for repeated measures; Means followed by equal letters do not differ and means followed by different letters differ from each other: post-hoc Bonferroni.

Table 3 - Mean Difference activation values, according to electromyography signal (EMG)

\begin{tabular}{|c|c|c|c|c|c|}
\hline \multicolumn{6}{|c|}{ Mean Difference } \\
\hline & & RF & VM & $V L$ & GM \\
\hline \multirow[t]{2}{*}{$1 \mathrm{~km} / \mathrm{h}$} & $4 \mathrm{~km} / \mathrm{h}$ & $0.006(P=0.36)$ & $0.004(P=1)$ & $0.001(P=1)$ & $0.005(P=0.13)$ \\
\hline & Overground & $-0.021(P=0.00)^{*}$ & $-0.026(P=0.00)^{*}$ & $-0.019(P=0.00)^{\star}$ & $0.021(P=0.09)$ \\
\hline $4 \mathrm{~km} / \mathrm{h}$ & Overground & $-0.027(P=0.00)^{*}$ & $-0.030(P=0.00)^{*}$ & $-0.020(P=0.00)^{*}$ & $-0.026(P=0.03)^{*}$ \\
\hline
\end{tabular}

Note: RF - Rectus Femoris; VM - Vastus Medialis; VL - Vastus Lateralis; GM - Gluteus Maximus; *ANOVA for repeated measures followed by post-hoc Bonferroni: mean difference with the $95 \%$ confidence interval. There is a difference between the walker group and the other two groups. The same did not occur between the treadmill group at $1 \mathrm{~km} / \mathrm{h}$ and at $4 \mathrm{~km} / \mathrm{h}$.

Comparing muscle activation of rectus femoris muscle in patients with both upper motor neuron injury and lower motor neuron injury in all gait training modalities, there was no statistically significant difference; ie., spasticity or flaccidity, originating from the type of affected neuron, does not alter the muscle activation in gait training (Table 4).

Table 4 - Muscle activation of Rectus Femoris X Flaccid and Spastic

\begin{tabular}{cccc}
\hline & \multicolumn{2}{c}{ Average of Muscle Activation RF (SD) } & \\
\hline & Flaccid & Spastic & p-value* \\
Treadmill $\mathbf{~ k m / h}$ & $16.5 \mu \mathrm{V}(3.59)$ & $15.64 \mu \mathrm{V}(7.59)$ & 0.437 \\
Treadmill $4 \mathrm{~km} / \mathrm{h}$ & $22.11 \mu \mathrm{V}(8.75)$ & $20.78 \mu \mathrm{V}(20.79)$ & 0.244 \\
Overground & $11.31 \mu \mathrm{V}(0.94)$ & $11.18 \mu \mathrm{V}(1.30)$ & 0.788 \\
\hline
\end{tabular}

Note: RF - Rectus Femoris; $\mu \mathrm{V}$ - microvolts; Mean values and standard deviation; * Student t-test.

Significant correlations of FIM with muscle activation were not found, both in the $1 \mathrm{~km} / \mathrm{h}(\mathrm{r}=-0.342 ; \mathrm{p}=0.304)$ and $4 \mathrm{~km} / \mathrm{h}$ training $(\mathrm{r}=-0.498 ; \mathrm{p}=0.127)$ and in the walker $(\mathrm{r}=-0.521 ; \mathrm{p}=0.100)$. 


\section{Discussion}

Through the electromyographic signal (EMG), this study compared muscle activation levels during gait on body weight-support treadmill and overground in incomplete spinal cord injured patients. The results showed increased electrical activity in body weightsupport gait training on a treadmill when compared to body weight-supported training overground of the muscles rectus femoris, vastus medialis, vastus lateralis, and gluteus maximus.

Gait is one of the most important functional movements of the human being and when it is damaged due to spinal cord injury, training is essential for the development of new ambulation strategy [20]. Body weight-supported locomotor training became a widespread and valuable training method within the rehabilitation of patients with spinal cord injury [21].

Even in individuals with severe spinal cord injury, when no more spontaneous recovery can be expected, locomotor capacity can be improved by gait training with assisted movements of the legs with controlled weight unload [22 - 24]. Besides facilitating neuronal plasticity, it is expected that there is a change in muscle properties associated with training, as well as contribution to improvement of the function achieved during such a specific training in the stable phase of a spinal cord injury [22].

Standing up on a moving treadmill, subjects with spinal cord injury are enabled to perform rudimentary gait movements. Such movements evoke an adequate afferent input to the activation of muscles of the legs comparable to those used during normal gait [25]. The weight reduction replaces uncontrolled spinal reflex patterns and compensates the losses of motor pattern. Gait training on a treadmill strengthens the principals of motor learning, favoring specific tasks based on repetitive movements [20].

When the afferent input is provided by a treadmill in motion, the central pattern generator in the spinal column is activated and evokes innate rhythmic behaviors such as walking. CPG is a complex model that involves bilateral sequential activation of muscles acting in different joints, each one having its own characteristics amplitude and speed of movement, being responsible for producing a cyclic gait pattern even after spinal cord injury [26, 27,4].

GPC activation during the treadmill training could promote neural plasticity processes, regulating the interaction between GPC and the peripheral reflex activity. Gait training stimulates the neuronal activity and activates the spinal cord centers of locomotion control. Thus, synaptic and cellular responses of the CPG control circuits could be more flexible or more appropriately modulated on the treadmill than on the ground [28]. This statement is in line with the present study which confirms that gait on the treadmill produces greater muscle activation compared to gait on the treadmill which confirms that gait on the treadmill produces greater muscle activation in relation to on overground walker.

During gait training, the moving surface of the treadmill provides biomechanical assistance for the support phase and neuronal assistance for the beginning of the swing phase. During the support phase, the assistance on the treadmill moves the leg and promotes hip extension during the terminal support. During the terminal support, the excitement of stretch receptors in the hip flexors interacts with the circuits of the central pattern generator circuits in the spine, promoting the cessation of the support phase and the beginning of the swing phase [26].

Based on the rhythmicity offered by the treadmill, it may seem logical to assume that the locomotor training on the treadmill offers advantages over the gait training in the walker for people with incomplete spinal cord injury [23], as also exposed by the data found in this study. Our findings show that the treadmill speed does not seem to be related to the levels of muscle activation during body weight-supported gait training although there was a tendency for increased muscle activation at a higher speed. Nevertheless, Meyns et al. showed that electromyographic progress in walking ability is more optimally expressed when testing occurs at a low rather than at high treadmill speed [29].

In the current literature, there are studies showing the benefits of using the treadmill with body weight support over other forms of treatment related with the gait of spinal cord injured individuals, for example, with the use of conventional physiotherapy $[30,12]$. There are a small number of studies comparing the efficiency of body weight-supported gait training on the treadmill with overground training, one of them is the study by Senthilvelkumar, Magimairaj, et al.[19] in individuals with traumatic incomplete tetraplegia. They conclude that both interventions can improve the locomotion of the studied population, however, they did not develop a muscle comparison between them. Another study comparing gait trainings was in individuals with chronic incomplete spinal cord injury, evaluating the walking 
speed, balance, muscle strength, and quality of life. The studies show that individuals with spinal cord injury can improve the walking capacity and psychological well being after a period of locomotor training, regardless of the method of training [31]. Despite such studies show that there is no difference between the types of gait training in the evaluated parameters, none of them was specific about muscle activation as is the case of this study.

This study has some limitations, such as the imprecision related to the weight supported by the individuals. The weight support was offered, however only the position of the individual over the hip suspensory in both modalities of gait training and not numerically.

\section{Conclusion}

Body weight-support gait training showed greater muscle activation in the rectus femoris, vastuslateralis, vastusmedialis, and gluteus maximus in training on the treadmill when compared to overground training in individuals with incomplete spinal cord injury. Muscle activation was independent of treadmill speed. Thus, body weight-supported gait training on the treadmill can propitiate a better performance in locomotor training for incomplete spinal cord injured individuals. These results contribute for the physiotherapy practice based on evidences for the rehabilitation of this population.

\section{References}

1. Luk KHK, Souter MJ. Spinal Cord Injury. In: Khan Z. (eds) Challenging Topics in Neuroanesthesia and Neurocritical Care. Springer; 2017. p. 83-95

2. WHO. World Health Organization. Spinal cord injury. Key facts. [Online]; 2013 nov 19. [cited 2016 Fevereiro. Available from: <http://www.who.int/mediacentre/ factsheets/fs384/en/>.

3. Center, N.S.C.I.S. 2014 Annual Statistical Report for the Spinal Cord Injury Model

4. Systems Public Version. University of Alabama at Birmingham: Alabama; 2014.
5. Rossignol S, Schwab M, Schwartz M, Fehlings MG. Spinal Cord Injury: Time to Move? J. Neurosci. 2007;27(44):11782-92.

6. Field-Fote E, Yang JF, Basso DM, Gorassini MA. Supraspinal Control Predicts Locomotor Function and Forecasts Responsiveness to Training after Spinal Cord Injury. J Neurotrauma. 2017;34(9):1813-1825. doi: 10.1089/neu.2016.4565.

7. Dutra CMR, Dutra CMR, Moser ADL, Manffra. EF. Treino locomotor com suporte parcial de peso corporal na reabilitação da lesão medular: revisão da literatura. Fisioter. Mov. 2013;26(4):907-920.

8. Cheung EYY, Ng TKW, Yu KKK, Kwan RLC, Cheing GLY. Robot-Assisted Training for People With Spinal Cord Injury: A Meta-Analysis. Arch Phys Med Rehabil. 2017;98(11):2320-2331.e12. doi: 10.1016/j. apmr.2017.05.015.

9. Wilson MS, Qureshy H, Protas EJ, Holmes S, Krouskop TA, Sherwood AM. Equipment specifications for supported treadmill ambulation training. J Rehabil Res Dev. 2000;37(4):415-422.

10. Sullivan KJ, Knowlton BJ, Dobkin BH. Step Training With Body Weight Support: Effect of Treadmill Speed and Practice Paradigms on Poststroke Locomotor Recovery. Arch Phys Med Rehabil. 2002;83(5):683-91.

11. Dobkin BH, Apple D, Barbeau H, Basso M, Behrman A, Deforge D, et al. Methods for a Randomized Trial of Weight-Supported Treadmill Training Versus Conventional Training for Walking During Inpatient Rehabilitation after Incomplete Traumatic Spinal Cord Injury. Neurorehabil Neural Repair. 2003;17(3):153-67.

12. Kurz MJ, Stuberg W, DeJong S, Arpin DJ. Overground body-weight-supported gait training for children and youth with neuromuscular impairments. Phys Occup Ther Pediatr. 2013;33(3):353-65. doi: 10.3109/01942638.2013.771719.

13. Lucareli PRG. Treino de marcha com suporte de peso em pacientes com lesão medular. São Paulo: Faculdade de Medicina da Universidade de São Paulo; 2009.

14. ASIA. Reference Manual for International Standarts for Neurological Classification of Spinal Cord Injury. Chicago: American Sinal Injury Association; 2003. 
15. Riberto M. Orientação funcional para a utilização da MIF. São Paulo: Universidade de São Paulo, Instituto de Medicina Física e Reabilitação do Hospital das Clínicas; 2005.

16. Dobkin B, Apple D, Barbeau H, Basso M, Behrman A. Weight-supported treadmill vs over-ground training for walking after acute incomplete SCI. Neurology. 2006;66(4):484-493.

17. Bohannon RW, Smith MB. Interrater reliability of a modified Ashworth scale of muscle spasticity. Phys Ther. 1987;67(2):206-7.

18. Stegeman DF, Hermens HJ. Standards for surface electromyography: the European project Surface. Nijmegen: Institute of Neurology, Department of Clinical Neurophysiology; 2013.

19. Behrman AL, Harkema SJ. Locomotor Training After Human Spinal Cord Injury: A Series of Case Studies. Phys Ther. 2000;80(7):688-700.

20. Senthilvelkumar T, Magimairaj H, Fletcher J, Tharion G, George J. Comparison of body weightsupported treadmill training versus body weight-supported overground training in people with incomplete tetraplegia: a pilot randomized trial. Clin Rehabil. 2015;29(1):42-9. doi: $10.1177 / 0269215514538068$.

21. Dietz V. Body weight supported gait training: from laboratory to clinical setting. Brain Res Bull. 2009;78(1):IVI. doi: 10.1016/S0361-9230(08)00410-3.

22. Morawietz C, Moffat FL. The effects of locomotor training after incomplete spinal cord injury: a systematic review. Arch Phys Med Rehabil. 2013;94(11):2297-2308

23. Harkema SJ, Hillyer J, Schmidt-Read M, Ardolino E, Sisto SA, Behrman, AL. Locomotor training: as a treatment of spinal cord injury and in the progression of neurologic rehabilitation. Arch Phys Med Rehabil. 2012;93(9):158897. doi: 10.1016/j.apmr.2012.04.032.

24. Field-Fote EC, Roach KE. Influence of a locomotor training approach on walking speed and distance in people with chronic spinal cord injury: a randomized clinical trial. Phys Ther. 2011 Jan; 91(1): 48-60.
25. Hubli M, Dietz V, Bolliger M. Spinal reflex activity: a marker for neuronalfunctionality after spinal cord injury. Neurorehabil Neural Repair. 2012;26(2):188-96. doi: $10.1177 / 1545968311420844$.

26. Dietz V, Harkema SJ. Locomotor activity in spinal cord-injured persons. J Appl Physiol (1985). 2004;96(5):1954-60.

27. Hiebert GW, Whelan PJ, Prochazka A, Pearson KG. Contribution of hind limb flexor muscle afferents to the timing of phase transitions in the cat step cycle. J Neurophysiol. 1996;75(3):1126-37.

28. Dietz V. Spinal cord pattern generators for locomotion. Clin Neurophysiol. 2003;114(8):1379-89.

29. MacKay-Lyons M. Central Pattern Generation of Locomotion: A Review of the Evidence. Phys Ther. 2002;82(1):69-83.

30. Meyns P, Van de Crommert HWAA, Rijken H, van Kuppevelt DHJM, Duysens J. Locomotor training with body weight support in SCI: EMG improvement is more optimally expressed at a low testing speed. Spinal Cord. 2014;52(12):887-93. doi: 10.1038/sc.2014.172.

31. Postans NJ, Hasler JP, Granat MH, Maxwell DJ. Functional electric stimulation to augment partial weight-bearing supported treadmill training for patients with acute incomplete spinal cord injury: A pilot study. Arch Phys Med Rehabil. 2004;85(4):604-10.

32. Alexeeva N, Sames C, Jacobs P, Hobday L, Distasio MM, Mitchell SA. Comparison of training methods to improve walking in persons with chronic spinal cord injury: a randomized clinical trial. J Spinal Cord Med. 2011;34(4):362-79. doi: 10.1179/2045772311Y.0000000018.

Received in 07/05/2017 Recebido em 05/07/2017 Recibido en 05/07/2017

Approved in 06/11/2018 Aprovado em 11/06/2018 Aprobado en 11/06/2018 